\title{
Stř́pky vzpomínek k sedmdesátinám dr. Michala Svatoše
}

Sám Michal Svatoš rád v nadsázce hovoří o svých narozeninách jako o „nejtragičtější události českých dějin“. Na svět totiž přišel v den 327. výročí bitvy na Bílé hoře. Osmého listopadu 2017 jsme si tak znovu připomněli nejen onu českou historiografií tolikrát démonizovanou srážku u letohrádku Hvězda, ale i kulaté životní jubileum historika a archiváŕe, který zasvětil celý svůj profesní život starším dějinám pražské univerzity. A protože jeho biografický medailon (z pera Josefa Petráně) i tehdy kompletní bibliografie jeho prací již byly publikovány v čísle tohoto časopisu, které mu bylo dedikováno před deseti lety, ${ }_{1}^{1}$ rádi bychom nyní doplnili několik vzpomínek od nás, jeho žáků.

Prosopografický seminář dr. Michala Svatoše byl v druhé polovině 90. let minulého století z hlediska výuky historie na Filozofické fakultě UK zcela marginální záležitostí. Scházeli jsme se v počtu čtyř až šesti, zcela výjimečně sedmi osob prímo v pracovně vyučujícího v Ústavu dějin a archivu Univerzity Karlovy - zpočátku každý týden, později, v době doktorských studií, už jen jednou do měsíce. Přesto však právě tato setkání měla pro všechny přítomné studenty povahu jakéhosi iniciačního zážitku, který nás od té doby provázel a stále provází nejen v profesním, ale mnohdy i osobním životě.

Ale nepředbíhejme. Do uvedeného semináře jsme se vesměs přihlásili pod dojmem výběrové přednášky dr. Svatoše, která byla několik let pravidelnou součástí nabídky Ústavu českých dějin FF UK. Zpočátku se konala v pracovně tehdejšího ředitele ÚDAUK prof. Petráně, později př́mo na fakultě, $v$ učebně č. $201 \mathrm{~s}$ historickým nábytkem. Úroveň přednášky dalece převyšovala mnohé z toho, co jsme byli zvyklí na fakultě slýchat. Pan doktor Svatoš prostě uměl zaujmout, navíc neustále propojoval minulost univerzity s její současností. Každá dvouhodinovka tak před námi otevírala barvitý př́iběh univerzity jako společenství mistrů a studentů, jež dalo základ dnešním akademickým svobodám. A ještě jedna věc byla na přednášejícím hned od začátku nápadná - oslovení „kolegyně a kolegové“ neznělo $\mathrm{z}$ jeho úst jako prázdná fráze, ale $\mathrm{v}$ duchu středověkých univerzitních tradic otvíralo bránu ke skutečně partnerskému vztahu mezi učitelem a žákem.

Prioritním motivem k zapsání se do diplomového semináře právě u externisty dr. Svatoše tak byla pro většinu $\mathrm{z}$ nás právě jeho osobnost. Zaujetí vlastním tématem přišlo zpravidla až postupem času - a opět jej měl na svědomí náš učitel. Všem členům semináře bezesporu uvízla v paměti podkrovní pracovna dr. Svatoše s výhledem na obrovský kaštan uprostřed vnitřního dvora univerzitního komplexu Celetná-Karolinum. Obří starožitný pracovní stůl u okna byl pokrytý v několika vrstvách odbornými publikacemi a jejich xerokopiemi. U ostatních třech stěn místnosti nepravidelného půdorysu stála knihovna se hřbety knih nadepsanými snad $\mathrm{v}$ deseti různých jazycích. Pouze při jedné stěně sahala tato knihovna jen do výše pasu. Nad ní na naše diskuse dohlížel ze své rektorské podobizny sám Josef Pekař. Knihovna, ačkoli byla místy rovnána na policích do dvou řad knih za sebou, i tak 
zjevně nestačila. Další svazky byly vyskládány v nevysokých „komíncích“v různých koutech pracovny přímo na zemi. $V$ rohu u okna pak byl umístěn na stolku počítač a uprostřed místnosti malý kulatý stůl, kolem nějž jsme sedávali.

Michal Svatoš byl mimořádně vstřícný školitel, který nám ochotně poskytoval nejen odborné znalosti, ale i přístup do své soukromé knihovny a celou šśři svých rozsáhlých zahraničních badatelských kontaktů. Jeho obětavost neznala hranic. Např́íklad níže podepsanému tehdejšímu diplomantovi značně komplikovala psaní jeho magisterské práce skutečnost, že neměl vlastní počítač ani tiskárnu. Dr. Svatoš v situaci, kdy byl ohrožen termín odevzdání práce, neváhal a vystresovanému diplomantovi přenechal na plné dva týdny (!) svoji pracovnu včetně počítače. Sám pracoval z domova a do zaměstnání docházel pouze na schůzky a jednání; jen občas si ze své vlastní pracovny odnesl domů nějakou knihu, prŕípadně ještě mezi dveřmi zodpověděl dotazy diplomanta.

Ačkoli dr. Svatoš své žáky cíleně nechtěl (či neuměl?) stresovat, jeho nároky rozhodně nebyly nízké. Všichni jsme např́klad museli nastudovat některou z cizojazyčných monografí $\mathrm{k}$ tématu a poté o ní referovat ostatním, přesně tak, jak nám to několikrát předtím předvedl sám náš vyučující. Nutno asi poznamenat, že to pro nás, generaci Husákových dětí, která vyrostla na povinné ruštině, představovalo poměrně náročný úkol. Zcela př́iznačné pro pedagogický styl Michala Svatoše bylo, že nám na přečtení knihy a př́ípravu referátu ponechal v podstatě tolik času, o kolik jsme si řekli, klidně třeba půl roku, a neustále nabízel možnost konzultací. Výsledkem byl nakonec nejen onen požadovaný referát, ale také a hlavně - nalezení vlastní sebedůvěry. Osvojili jsme si potřebnou terminologii v daném jazyce, uvykli na jeho odborný styl a najednou pro nás zahraniční literatura přestala být strašákem, naopak jsme ji začali sami vyhledávat a lačně hltat.

Podobně jsme se prokousávali přepisem matriky středověké pražské právnické univerzity a zejména výstavbou prosopografické databáze. Devadesátá léta byla pionýrskou dobou osobních počítačů a začínajícího internetu. Dr. Svatoš jako jeden z prvních mezi českými historiky pochopil, že počítač může být více, než jen vylepšený psací stroj. Pod vlivem zahraničních výzkumů vsadil na nové metody i technologie, které se ale stejně jako my teprve učil „,za pochodu“ používat. Pracně vystavěná databáze v programu Paradox je sice $\mathrm{z}$ hlediska dnešních IT technologií pravěkou vykopávkou, ale $\mathrm{v}$ zásadě pořád funguje. Zvláště zajímavá a nejednou komplikovaná byla také spolupráce mezi námi historiky a programátory. Už jenom nalezení společného jazyka bylo (a dodnes mnohdy je) oříškem! V podobném duchu následovalo objevování možností internetu a koketování s digitalizací nejcennějších pramenů.

To však již prosopografický seminář nebyl pro většinu z nás diplomovým, ale doktorským. Scházeli jsme se sice méně pravidelně, o to více jsme ale využívali možnosti zahraničních stáží. Také jsme objižděli své první konference a publikovali první studie v časopisech a sbornících - zpočátku ještě jako tým, později už i jako jednotlivci, sledující svoji vlastní specializaci. Jinak se ale př́liš nezměnilo. Ona dělná týmová spolupráce i laskavé vedení dr. Svatoše zůstávaly charakteristickým rysem semináře. A opět můžeme toto tvrzení ilustrovat řadou konkrétních vzpomínek, třeba tou, jak se jeden z doktorandů setkal víceméně náhodou se svým školitelem v Mnichově - a po následující dva dny se mu dostalo podrobné komentované prohlídky města, všech zdejších významných knihoven a v neposlední řadě samožrejmě univerzitního archivu. 
Když se naskytla př́ležitost, stal se v roce 2000 tým prosopografického semináře dr. Svatoše základem Modulu biografie a prosopografie nově vzniklého Výzkumného centra pro dějiny vědy, společného pracoviště AV ČR a Univerzity Karlovy v Praze. V jeho rámci jsme měli dosud získané zkušenosti s prosopografií a databázemi aplikovat na novověký materiál. Rozsáhlá Databáze české vědy 1882-2000 byla sice vytvořena, ovšem jejímu systematičtějšímu vyplňování a zejména vyhodnocování zabránila změna vědní politiky ČR, která opustila dosavadní koncepci výzkumných center a ta tudíž až na drobné výjimky zanikla. Je ovšem také pravdou, že někteří členové Svatošova modulu nesli poněkud těžce skutečnost, že jim vzhledem k uvedenému hlavnímu úkolu nezbývalo mnoho času na výzkum vlastních témat, takže z centra odešli o něco dříve sami.

Prosopografický seminář dr. Svatoše se tak zhruba po deseti letech své existence rozpadl. Jeho bývalí členové jsou ovšem nadále v kontaktu a k panu doktorovi se jako ke svému učiteli s hrdostí hlásí. Vštípil nám úctu $\mathrm{k}$ univerzitní tradici a zasvětil nás do jejích dějin. Naučil nás kriticky myslet a nebát se zkoušet nové věci. Zakusili jsme s ním synergii i rizika týmové práce i mezioborového usilování. Především však pro nás zůstává ztělesněním ideálu učitele, jenž kolem sebe s nenucenou grácií šíří kolegiální a přátelskou atmosféru, která studenty uklidňuje a osvobozuje, zároveň však motivuje a zavazuje. A v neposlední řadě mu vděčíme za mnohé otevřené diskuse, $\mathrm{z}$ nichž vzešla přátelství trvající dodnes.

Ad multos annos, pane doktore!

Jana Borovičková - Jiří Stočes doi: $10.14712 / 23365730.2018 .55$

\section{Bibliografie prací Michala Svatoše - dodatek za leta (2002) 2006-2018}

Bibliografie je řazena chronologicky, v jednotlivých letech studie a články jsou předřazeny recenzím a zprávám. V záznamech je uvedeno jméno Michala Svatoše v př́ípadě, kdy není jediným autorem textu. Bibliografie navazuje na Bibliografii prací Michala Svatoše, která vyšla v AUC-HUCP, 47/1-2 (2007), s. 13-33, případně doplňuje záznamy, které v této bibliografii nebyly uvedeny.

\section{2}

Metryka uczniów Torunskiego Gimnazjum Akademickiego 1600-1817, I-II. Zenon Hubert Nowak, Janusz Tandecki (eds.). Toruń: Towarzystwo Naukowe w Toruniu, 1997. Acta Comeniana, 2002, 15-16 (39-42), s. 417-419. ISSN 0231-5955.

\section{6}

Smlouva o užívání Betlémské kaple z roku 1612, in: Mezi Baltem a Uhrami: Komenský, Jednota bratrská a svět středoevropského protestantismu: sborník k poctě Marty Bečkové. Praha: Filosofia, 2006, s. 209-222. ISBN 80-7007-246-6.

\section{7}

Frederick Lewis Snider (1941-2005). Kateřina Mašková, Michal Svatoš, Vladimír Urbánek. Acta Comeniana, 2007, 20-21 (44-45), s. 331-332. ISSN 0231-5955. 